\title{
An exploration of sustainability change agents as facilitators of nonformal learning: mapping a moving and intertwined landscape
}



\begin{abstract}
We explore the variety of ways in which change agents try to contribute to sustainable development and how, by doing so, they enable different forms of learning. Drawing on research literature as well as empirical studies, we distinguish a diversity of change agency roles. We then describe and develop an ideal typology of change agents according to how they relate to two fields of tension: that between instrumental vs. open-ended approaches to change and learning, and that between personal detachment vs. involvement. Finally, we compare the developed ideal types, i.e., Technician, Convincer, Mediator, and Concerned Explorer, with empirical examples and suggest a dynamic reading of the typology as a landscape in which change agents move between and across different positions according to changing and shifting contexts.
\end{abstract}

Key Words: change agents; ideal typology; nonformal learning; sustainability; transition

\section{INTRODUCTION}

The attempt of making our world more sustainable is widely regarded as one of the most important and difficult societal challenges today. In this context, a variety of actors strive to promote change toward sustainable development; some as part of their professional job, others as engaged citizens; some in private companies, others in public institutions, local communities, nongovernmental organizations, or virtual spaces. Such change agents are our focus here. In particular, we explore the variety of ways in which change agents try to contribute to sustainable development, and how, by doing so, they enable different forms of learning. Sustainability transitions are often framed as a matter of "learning by doing" and "doing by learning" (Loorbach 2007). We have to "learn our way out of unsustainability" (Finger and Asún 2001), it is argued, and in doing, so change agents play a key role. Most of them probably do not think of themselves as facilitators of a learning process; however, nonformal learning is a vital part of their practice and takes shape in varied ways. Often, these practices can be characterized as social learning, defined by Wildemeersch et al. (1998:252) as "the learning of groups, networks, communities and social systems, engaged in problem solving activities, in conditions that are new, unexpected, uncertain, conflicting and hard to predict."

Here, our aim is to explore the different ways in which change agency is approached, as a key to understanding social learning on sustainability issues. The remainder of this introduction briefly expands on the key concept of change agency in relation to sustainable development. Then, drawing on research literature as well as on our own findings in earlier empirical studies, we create some conceptual order in the variety of change agency practices by distinguishing different roles that change agents can take on and clustering these roles in four ideal types of change agents as facilitators of nonformal learning. This enables us to unfold a landscape in which sustainability change agents position themselves and navigate across different approaches to sustainability and learning. Hence, the presented typology requires a dynamic reading and is meant as a heuristic device that can be used analytically and theoretically by researchers but also has the potential to nourish change agents' professional reflection on their role and approaches to learning. Finally, we critically reflect on the rationale, risks, and limitations of our work by comparing the ideal typology with empirical examples.

\section{Change agents: history and definitions}

Since Lewin's (1947) pioneering work on change theory and experiments with training of change agents in the 1940s, the concept of change agents has been used as a specific social category to name those actors that play a significant role in "initiating, managing or implementing change" (Caldwell 2003:131). We deliberately use this very broad and descriptive definition of change agents because the term has been used in various contexts, referring to divergent meanings and manifestations. Criticizing how the concept became blurred by vague descriptions and one-dimensional perspectives, social scientists have conducted historical and synthetic reviews and tried to bring order to this somewhat obscure research field by developing classifications of change agency (e.g., Ottaway and Cooper 1976, Ottaway 1983, Caldwell 2003). Their work shows how the term has been used to refer to individual actors as well as groups or teams (e.g., Tichy 1975, Mayon-White 1993, Webber 1999), professional specialists with specific schooling and skills in managing change processes as well as actors with other expertise and competencies such as visionary leadership (e.g., Bennis 1964, Buchanan and Boddy 1992, Behling and McFillen 1996), and insiders as well as (consulted) actors from outside a particular system or organization (e.g., Beckhard 1969, Ginsberg and Abrahamson 1991). Furthermore, change agency can be formally invited or not (e.g., Bennis and Schein 1969, Zaltman and Duncan 1975), proactively initiated or a reaction to outside pressure (Tichy 1974, 1975), and both process and task oriented (e.g., Dale 1974, Saravanan 2015). The diversity revealed in such reviews and classifications shows that change agency cannot be captured in one single model and that it is impossible and undesirable to think of a generic type of change agent with a particular set of attributes or competencies that serves as an allinclusive recipe for success (Caldwell 2003). Here, we explore the 
variety of manifestations of change agency in the context of sustainable development as well as how the varied roles change agents can play enable different kinds of nonformal learning.

\section{Change agents and complex sustainability issues}

It would be problematic to try to understand change agency abstracted from the issue of change. Here, we focus on change agents engaged in the wide variety of attempts to make our society more sustainable. The specificity of this endeavor must be taken into account in the construction of our ideal typology.

Sustainability issues are often considered to be "wicked problems" (Pryshlakivsky and Searcy 2013), which are characterized by complex interactions, multiple causation and feedback loops, radical uncertainty of knowledge grounds, and contestation of facts, values, and norms. As a result, they do not lend themselves to consensual measurement, prediction, and control according to the established standards of disciplinary scientific expertise and traditional decision-making routines. We think that Hoppe's (2010) distinction (see Fig. 1) between structured, moderately structured, and unstructured (or wicked) problems interestingly captures and illuminates this idea and can therefore be helpful to understand and reflect on different change agency practices. As we will show in our discussion of the ideal typology, change agents can take on different roles in response to the presence or lack of agreement on norms and values and certainty on required and available knowledge about sustainability problems and their solutions.

Fig. 1. Characteristics of structured, moderately structured, and unstructured problems.

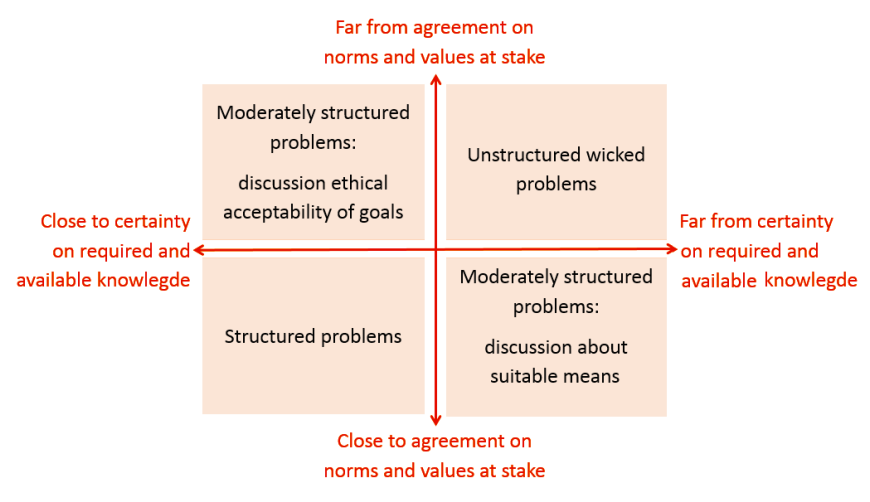

Considering the omnipresent factual and normative controversies surrounding sustainability issues, sustainability change agency is always related to political struggles on what, how, who, why, and when to change. It is often emphasized that sustainability problems are "matters of public concern" in which diverse actors are jointly involved and in which irreconcilable private and public interests, passions, commitments, values, ideals, concerns, etc. are intimately entangled (Marres 2005). Thus, viewing sustainability challenges as normative and political issues, which implies struggle over different competing alternatives, differs considerably from approaching change from a managerial perspective. Taking a political perspective, change agency practices cannot be reduced to value-free implementation of the proper techno-scientific solutions for unambiguously defined problems. Rather, it is a matter of engaging with the multidynamic complexity of wicked problems, including tensions between stability and change, short term and long term, local and global, rich and poor, etc., without certain foundations based on uncontested scientifically true solutions (Ashley 2000) or universal ethical guidelines (Sund and Öhman 2014).

\section{METHODS}

To explore of the variety of manifestations of sustainability change agency and how these enable different kinds of learning, we identify different change agent roles and map them in four categories provided by two fields of tensions.

\section{Identifying change agency roles: literature study and case-study research}

As noted, the concept of change agents is used in different meanings in the research literature. Also, in our own empirical studies, we have met people that we have characterized as change agents and even differentiated in different types (Læssøe 2001, 2008). Here, we bring together findings from the literature and empirical research to identify and map the many different roles that change agents can assume.

Empirically, we draw on diverse studies in Denmark and Belgium. In Belgium, we observed change agents in eight case studies of varied formal and nonformal environmental and sustainability education (ESE) practices: an environmental education center, an organization that offers workshops for ecological behavior change for adults, a grassroots community center, the "Environmental Performance at School" (MOS) project, the "Transition Towns Network" in Flanders, a transition arena aiming to make a city climate neutral, a community-supported agriculture (CSA) farm, and a transition initiative at Ghent University. The empirical data consisted of 78 documents, 19 transcripts of audio-recorded indepth interviews, and 45 sets of field notes and transcripts of video-recorded direct observations of educational activities that varied in duration from $30 \mathrm{~min}$ to $8 \mathrm{~h}$. In Denmark, an evaluation project of a national Green Guide Scheme was conducted from 1997 to 2000. The scheme enabled local stakeholders to join forces to promote citizen-consumer participation in local sustainable development. In total, > 100 Green Guide projects, lasting between 3 and 6 years, were supported economically as well as by offering in-service training courses. The evaluation was approached as an interactive research and process evaluation, including 41 interviews, 14 group interviews, six surveys, observations of annual meetings, and in-service training courses, as well as analyses of policy documents, log books, applications, and annual reports.

Our methodological approach for identifying and mapping change agent roles is inspired by the attentiveness for similarities and differences that is, for example, theoretically elaborated in the later work of Wittgenstein (2010; see also Öhman and Östman [2008], who applied this way of working for classifying ESE practices), and that methodologically underpins analytical frameworks developed in discourse theory (Starks and Brown Trinidad 2007). We identified change agency roles by collecting and systematizing similarities and differences between diverse roles that change agents can take on that we found in research literature as well as empirical observations. More precisely, we focused on similarities and differences that make manifest how 
change agents can draw on different roles to initiate, manage, or implement change. We conducted this analysis through an iterative process of scrutinizing research literature on change agents as well as our empirical observations and contrasting our theoretical and empirical findings. We started with identifying basic features of how change agents can initiate, manage, or implement change processes in the literature we reviewed and contrasted these with concrete examples and situations from our empirical material. We then looked for empirical examples that were not covered by the features found in the literature. Cyclically repeating this identification strategy resulted in a long list of different possible change agency roles. Finally, we gradually refined and reassembled these roles by comparing them to each other. Through this comparison of similarities and differences between situations, we eventually developed the change agency roles whereby each role shares some characteristics that are, at the same time, clearly different from the shared characteristics that were constitutive for the other roles. It was thus the criterion of internal homogeneity and external heterogeneity (Patton 2002) that guided our investigation. Being aware of overlaps, we can maintain that each of the roles represents a certain quality which is not totally covered by one of the others.

\section{An example to clarify our methodology}

Within the scope of this article it is impossible to explain and substantiate in detail how we used this methodology. However, we will illustrate it with an example. In the reviewed literature, we found that Schein (1996) described a particular kind of change agent as a "good role model." Through mentoring and socialization in families, schools, companies, religious movements, and other organizational settings, change agents can inspire and initiate change, Schein argues, by serving as a role model with whom people can positively identify. By being exposed to such a role model, people can become motivated for change and able to understand something from a new perspective. Comparing this theoretical concept of the change agent as a good role model with the empirical manifestations of change agency that we observed, we recognized clear similarities between this theoretical concept and several empirical observations. In interviews, for instance, school teachers participating in the MOS project repeatedly emphasized the importance of setting a good example:

Teacher: "But we ourselves should take care not to waste... or that we unnecessarily, yes..."

Interviewer: "Do you think that is important, not to waste things yourselves?"

Teacher: "Yes, because in the end we have to set the good example."

Further scrutinizing the empirical data looking for similar change agency roles, however, we found a clear difference between two types of roles that are both related to Schein's (1996) concept of the role model. Some change agents such as the teacher described above deliberately and consciously try to act as a role model with a particular goal in mind (e.g., making students follow their good example), whereas other empirical examples can be viewed as unintended role models. For the CSA-farmer we observed, for instance, it was very important to run his farm according to his own ideals and convictions.

I think that agriculture has a very important role to play. We are the primary sector. That's why I also chose the

\begin{abstract}
farming business. Well, like, how can you change the world, eh? When you're 45, you think, right, what else is there for me to do in life and then I thought, OK, that's what I'm going to do. That's something I am really going to go for. I am really going to do it well, you know? And whatever the cost I will shoot myself in the foot and earn less. I used to work in TV where I earned about eight times as much. And now I don't, but OK, I am happier and I really feel like I am doing something useful.
\end{abstract}

Although he did not deliberately try to set a good example, his way of working and being can have the unintended outcome of inspiring people to change their way of thinking and doing (see also Van Poeck and Vandenabeele 2014). In our classification of change agency roles, we took the identified similarities and differences into account by distinguishing between the roles of an "exemplar" and a "do-gooder," two categories that are internally homogeneous and externally heterogeneous.

The result of this systematic process of identifying and mapping different change agency roles is the ideal typology of sustainability change agents as facilitators of nonformal learning that is presented next.

\section{Toward an ideal typology: mapping change agents' roles on two} axes

As a basis for mapping the variety of roles, we constructed a matrix by combining two fields of tension that are particularly relevant in light of the specific, wicked nature of sustainability issues and in relation to how such issues can be subjects for learning.

\section{Instrumental vs. open-ended}

The first axis of the matrix is constituted by a tension between an instrumental and an open-ended approach to change and learning. Whereas notions such as planned change and managed learning are extensively elaborated in literature on change agency, critics question the "illusions of manageability" (Caldwell 2003) implied in mechanistic, linear, and instrumental conceptions of initiating and implementing change processes. A similar tension nourishes discussions about education in relation to sustainability. Several ESE researchers have criticized an instrumental focus on teaching and learning the proper attitudes, knowledge, behavior, skills, etc., in view of the desired transformation of individuals and society at large, which they consider to be at odds with concerns for democracy, critical reflection, and enlightened and qualified action (Blewitt 2005, Mogensen and Schnack 2010, Sund and Öhman 2014). Despite various nuanced positions, this debate reveals a sharp opposition between two extremes: an instrumental perspective based on the transfer of non-negotiable, factual, behavior guidelines vs. a pluralistic approach that grants every opinion equal value. Whereas the problem with the former is that it easily neglects uncertainties and controversy (Breiting 2009), the latter runs the risk of resorting to undue relativism regarding the implications of sustainability issues (Kopnina 2012).

Because it might be tempting to view this field of tension from a dichotomist, polemical perspective, we emphasize that, in our view, it cannot be reduced to an oversimplified distinction between good vs. bad. Rather, as we have argued elsewhere (Læssøe 2007, Van Poeck et al. 2016), we face here a paradox brought about by the very ambiguous relation between democracy and 
sustainability. Acknowledging that both pertinent concerns are irreconcilable to a certain extent brings about thorny and inescapable dilemmas between caring about the far-reaching consequences of sustainability issues and restraints against forcing predetermined responses. Indeed, instrumental approaches to change and learning face their limits in confrontation with sustainability challenges. All the same, however, one might wonder how education can be "anything other than the achievement of some particular end" (Ferreira 2009:614). Is not all education purposive in some way or another? And should we not focus our attention, then, on the question of which particular purposes are most valuable or desirable instead of narrowing down this discussion to a decontextualized black-and-white opposition between instrumentalism vs. open-endedness?

\section{Personal detachment vs. personal involvement}

The matrix's second axis is constituted by a tension between personal detachment vs. involvement. In literature, change agents are often depicted as neutral agents oriented toward the process of change rather than toward the issues at stake. They are conceived as actors that facilitate change and help others with a change process "without themselves becoming involved in its content" (Dale 1974). Therefore, they are assumed to hold the proper, specialist schooling, expertise, and competences to facilitate and manage change professionally (Bennis 1964, Schein 1988, Buchanan and Boddy 1992). In contrast to such a neutral, detached position, especially in the context of sustainability, change agents are also often described as non-neutral, personally engaged actors driven by idealism (e.g., Walker 2006, 2007). Such so-called "fiery souls" (Wickenberg 2004) are, above all, committed to the issue at stake in the change process in ways in which personal identity and the issue at stake are deeply intertwined. Especially in oppositional minority groups, this personal engagement can be important for the empowerment and maintenance of the group identity and belief in the possibility of change. At the same time, in its extreme, it risks fueling a fanaticism undermining the minority groups' own ambitions of mobilizing people for their cases and promoting change (Wickenberg 2004, Marimaa 2011).

Here, too, it should be emphasized that this field of tension cannot be reduced to a dichotomist distinction that would conceal a much more nuanced reality in change agents' practices. First, detachment and involvement should not be understood as an either-or dichotomy with the detached position as the professional approach and the involved position as the emotiondominated activist approach. Furthermore, it is difficult, if not impossible, to separate the pure process from the issues at stake in it. A process-oriented change agent is thus always inevitably confronted with the content of sustainability challenges and the personal meaning-making and responses that go with this.

\section{RESULTS: AN IDEAL TYPOLOGY OF SUSTAINABILITY CHANGE AGENTS AS NONFORMAL EDUCATORS}

Combining the two tensions, we created a matrix with four ideal types of change agents: the Technician, the Convincer, the Mediator, and the Concerned Explorer. Each of these ideal types can draw on different roles to perform their change agency practices (Fig. 2), thereby applying different approaches to learning and sustainability. We should note that this is but one of many possible typologies. Our hope is that it contributes to clarifying and enriching the understanding of how different types of change agents, taking on different roles, can enable different kinds of learning.

Fig. 2. Ideal typology of change agents.

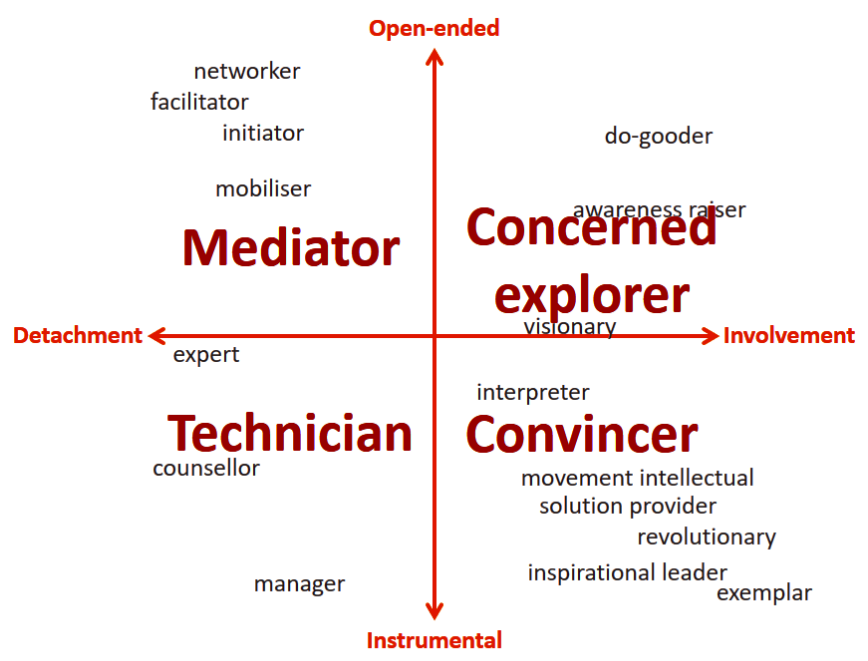

\section{The technician}

The combination of personal detachment and an instrumental orientation creates the Technician. The Aristotelian concept "techne" refers to a rationality characterized by concern with how to solve concrete issues. In accordance with this, technicaloriented change agents approach change as a matter of concrete problem solving. Following this rationality, sustainability transition is approached as a matter of technical knowledge and innovations followed by implementation, which in some cases also includes coping with socio-cultural factors. Similarly, learning becomes a matter of qualifying the learners as technicians by aiming at the acquisition of techno-scientific knowledge and practical skills in their working life as well as in the implementation of green technologies and practices in their everyday life as consumers. In this approach, the "qualification function" (Biesta 2009) of education is the main focus. In terms of "metaphors for learning," i.e., images that allow defining education and bringing forward fundamental assumptions behind educational theories and practices, Sfard (1998) has called this perspective on learning the "acquisition metaphor," which views education as the acquisition of knowledge, skills, ideas, meanings, facts, representations, etc. Knowledge and competences are then assumed to be achievements of individual learners that can be transferred and applied in different contexts. This rather mechanistic perspective on learning fits in a linear problem-solving model: specific techno-scientific solutions are sought for a particular problem, and learning processes are assumed to anticipate this desired outcome systematically (Vandenabeele and Wildemeersch 2012). As such, learning is result oriented rather than process oriented. As an ideal type, a technician approach is most relevant for dealing with what Hoppe (2010) characterizes as structured problems. Unlike the also instrumentally oriented Convincer, the Technician, in his or her 
pure ideal form, is personally detached from the values and emotions related to the issue and focuses on the problem solving per se. It is obvious that, for the Technician, epistemological values (related to "knowledge and truth regarding the world as it actually exists") take precedence over ethical values (in the domain of duty, virtue, and the good, and thus related to "what we ought to do" or "the way the world should be") and aesthetic values (that elicit various emotions such as pleasure and liking or displeasure and disliking; Garrison et al. 2015:189).

Change agents as Technicians can take on several of the roles we identified. Acting as a manager, they attempt to govern the entire change process by planning, organizing, directing, controling, and reviewing change strategies. In a counsellor role, they give very specific expertise-based advice and answers in relation to particular questions. Taking on the role of an expert, they try to foster change by providing expertise in the form of knowledge, insights, and facts. They explain theoretical insights, models, concepts, etc. that they consider helpful to inspire or encourage change (Table 1).

Table 1. Ideal typology and characteristics of sustainability change agents as nonformal educators.

\begin{tabular}{ll}
\hline \hline Change & Characteristic \\
agent & \\
\hline Mediator & $\begin{array}{l}\text { Open-ended and detached } \\
\text { Focus predominantly on subjectification } \\
\text { Learning as knowledge creation } \\
\text { Sustainability transitions as processing democratic } \\
\text { participation in deliberations on dilemmas and } \\
\text { disagreements }\end{array}$ \\
Explorer & $\begin{array}{l}\text { Open-ended and involved } \\
\text { Focus predominantly on subjectification }\end{array}$ \\
& $\begin{array}{l}\text { Learning as a response } \\
\text { Sustainability transition as a concern; search and } \\
\text { dialogue on concrete alternatives }\end{array}$ \\
& $\begin{array}{l}\text { Instrumental and detached } \\
\text { Focus predominantly on qualification }\end{array}$ \\
& $\begin{array}{l}\text { Learning as acquisition } \\
\text { Sustainability transitions as technical innovations and } \\
\text { Socio-cultural implementation }\end{array}$ \\
& $\begin{array}{l}\text { Instrumental and involved } \\
\text { Focus predominantly on socialization }\end{array}$ \\
& $\begin{array}{l}\text { Learning as acquisition and participation } \\
\text { Sustainability transitions as value-driven concrete } \\
\text { alternatives }\end{array}$ \\
\hline
\end{tabular}

\section{The convincer}

For this type of instrumental and involved change agent, sustainability is a matter of personal concern and commitment and is associated with values, beliefs, and emotions. The struggle for sustainability is an inherent part of the Convincer's life orientation and self-identity. Whereas the socio-cultural aspect of sustainability is affiliated with the techno-scientific project of the Technicians, the Convincer focuses predominantly on sociocultural changes with technical changes as affiliated parts. Sustainability transition becomes a matter of value-driven concrete alternatives. In educational terms, the Convincer's project is an enlightenment project trying to activate people, raise their consciousness, and (re)socialize them. Biesta (2009) refers to this as the socialization function of education. Learning is then aimed at the transfer of norms, values, beliefs, expectations, attitudes, behaviors, and identities that are highly valued by the educator. As such, the Convincer also contributes to learning as acquisition (Sfard 1998). However, the focus on activating people to help realize the Convincer's envisioned sustainability transition is also a manifestation of what Sfard (1998) calls the "participation metaphor." This is an image of education as the process of becoming a member of a certain community, which entails achieving the ability to act according to its particular norms. Within this metaphor, Sfard (1998) emphasizes, participation is understood as "taking part" and "being a part," which implies a process of becoming a part of a greater whole. This greater whole, into which Convincers working with sustainability issues try to socialize other people, is not identical with but rather is more or less in opposition to the state of the art in society. Thus, the idea of socialization and participation should not be understood as an affirmative orientation but rather as guided by a transformative resocializing ambition. Furthermore, from her or his personally involved position, the Convincer prioritizes aesthetical and especially ethical values over epistemological values. This does not mean that techno-scientific knowledge is irrelevant; in our modern society, the Convincer will draw on it as a highly legitimate underpinning of emotionally invested and normative values, beliefs, and worldviews. With a "true is," it becomes easier to convince others about a "true ought" (Garrison et al. 2015:187). This Convincer approach as an ideal type can be related to Hoppe's (2010) moderately structured problems, in particular, those for which there is a lack of agreement on values and norms that creates a space for the Convincer to strive for specific, value-driven choices.

A variety of roles exists in this instrumental and involved quadrant of the Convincer. Characteristic of many of these roles is their idealistic focus on radical change, be it individual or societal. Very strongly focused on societal change are change agents that act as revolutionaries, who strive to build alliances and counter power in the pursuit of fundamental social change. In contrast, change agents that take the role of an exemplar emphasize individual change. They set the good example and "walk the talk," and in doing so, deliberately aim to provide a model to be copied or imitated. Change agents in the role of an inspirational leader are focused at raising desirable and inspirational goals and values and strive to unite and empower followers to achieve those goals and ideals. As movement intellectuals, they translate existing knowledge into arguments that support a certain radical vision or movement. Convincer types of change agents can also act as solution providers, focusing on providing and convincing others to adopt ready-to-use solutions in view of the pursued change. As interpreters, they select and gather knowledge and present it in a form in which it makes sense in relation to a concrete case or issue (Table 1).

\section{The mediator}

The Mediator differs from the first two ideal types by not being instrumental with ready-made solutions at hand. In addition to being open-ended in relation to sustainable transitions, the Mediator is also characterized by taking a personally detached position as the impartial third party aiming at catalyzing participatory dialogue, learning, and creative innovation. The ambition of doing this is neither oriented toward promoting 
technical qualification nor value socialization, but is oriented toward open-ended, collective problem solving. This not only creates a concrete solution but also implies creative and reflective interactions among the participants that may enable transformative learning in the sense that it allows for double-loop learning, questioning, and transforming existing social and personal orientations (Argyris and Schön 1978, Mezirow 1991). Thus, the learning that takes place can be characterized by the "knowledge creation metaphor" that defines education in terms of "the pursuit of newness" (Paavola et al. 2004:562). In this image of education, the focus is on innovation, i.e., collectively creating new knowledge or transforming and further developing existing ideas and practices. Learners are not only consumers but also producers of knowledge. As such, the Mediator contributes to the three functions of education that Biesta (2009) described: qualification (e.g., by learning new skills or acquiring collectively created innovative knowledge), socialization (e.g., by adapting to the prevailing norms and expectations in the "innovative knowledge communities" [Engeström 1999] in which one takes part), and subjectification (e.g., by developing oneself as an independently and critically thinking person who explores different options and perspectives [Osberg and Biesta 2010, Hasslöf and Malmberg 2015]). Mediators conceive of sustainability transition as processes of socio-cultural learning and change enabled by democratic participation in deliberations on dilemmas and disagreements. Change agents who use the "transition management model" focus on the content as well as the process by organizing an interactive and selective participatory stakeholder searching process aimed at learning and experimenting (Loorbach 2007). They create forums or arenas of frontrunners that develop future visions and set up transition experiments. Without fixed goals, they try to empower other change agents to gain influence for their efforts to change society in a more sustainable direction. As such, they need to support and reinforce each other and each other's activities over the different levels and governance activities (Paredis 2013). The Mediator ideal type thus flourishs in relation to what Hoppe (2010) calls "moderately structured problems," either by engaging with the lack of agreement and certainty on required and available knowledge (i.e., by creating new knowledge) or by mediating negotiations and deliberations in the space created by a lack of agreement on values and norms.

The different roles that a Mediator type of change agent can take on share a focus on progressing the change process. Acting as an initiator, they start change processes by establishing initiatives that offer people opportunities to take part. Distinctive for change agents as mobilizers, they use communication competences to activate people. In a networker role, they gather a diversity of actors and perspectives; they bring actors together, include new perspectives by introducing new actors, and stimulate actors to share their perspectives. Performing a facilitator role, they help people, as a process expert, to think things out together. That is, they facilitate cothinking and cocreating instead of doing the actual change work themselves (Table 1).

\section{The concerned explorer}

The Concerned Explorer resembles the Convincer in being personally involved while sharing the open-endedness of the Mediator. She or he is not a neutral process catalyzer but takes part in sustainability transitions and related social learning processes driven by a personal concern for the issue at stake. The Concerned Explorer thus holds strong, emotionally invested opinions, values, and beliefs in relation to the issue at hand and may argue in favor of concrete solutions, but, contrary to the Convincer, he or she handles these personal values as contributions to explorative dialogues and mutual learning with other people. Learning, in this approach, occurs by enabling processes of social responsivity in which new ideas and pattern of thoughts occur in a mutual responsive playing exchange between the participants (Asplund 1987). With Illich's (1973) term, it is a process of conviviality in which the Concerned Explorer takes part. This perspective on education is also captured by the "response metaphor" (Vandenabeele and Wildemeersch 2012, Van Poeck and Vandenabeele 2014). Rather than viewing education in terms of equipping people to contribute to predefined solutions, this metaphor highlights the personal concern and the efforts made by a change agent to find a settlement for an issue that can incite an interesting educational process. By enacting their care for an issue, educators can appeal to learners' personal responses, that is, invite learners to respond to their questions, points of view, and experiences in full recognition of the antagonism, ambiguities, and differences that exist between them. Thus, Concerned Explorers fully recognize the lack of agreement on value and norms as well as the lack of certainty on required and available knowledge characterizing "unstructured problems" (Hoppe 2010). Instead of qualification or socialization, it is subjectification that is in the forefront. Following Håkansson et al. (2017), we distinguish between two forms of subjectification. First, "subjectification as perspective shifting," as described above with reference to Biesta (2009), may occur. Second, the educational dynamic fostered by a Concerned Explorer may also give rise to "subjectification as dismantling." This is not merely a shift between different, existing perspectives but a form of subjectification that is accompanied by a strong disidentification act: it establishes a way of being and doing that had no place in the existing order. Beyond critical thinking, often confined simply to "choosing among pre-existing alternatives," this understanding of subjectification emphasizes the importance of creativity and "imagining or creating new desirable [...] possibilities for the future" (Garrison et al. 2015:196).

Characteristic for this type of change agent roles is the attention and focus toward the content of the envisioned change, i.e., the issues at stake. Change agents can promote this focus by taking on the role of an awareness raiser, striving to make people aware of an issue, arouse interest in it, and call attention to it. Acting as a visionary, these change agents strongly focus on the future by envisioning change and proposing compelling future visions. Finally, change agents as do-gooders show some resemblance with the exemplar role described above, but the difference is that dogooders can be viewed as an unintended type of change agent. They also make efforts to act according to their own ideals and convictions, but they do so for reasons of personal motivation rather than to make an example for others. In effect, however, their way of being and acting plays a significant role in inspiring other people to change (Table 1).

\section{DISCUSSION: COMPARING THE IDEAL TYPICAL CHANGE AGENTS WITH EMPIRICAL EXAMPLES}

Ideal typologies are meant to make helpful theoretical distinctions, not to pigeon-hole concrete people (Weber 2011). 
They are inevitably decontextualized, whereas change agent practices should always be reflected, developed, and assessed in relation to specific historical processes, as well as current structures, cultures, and dynamics. In our case, the ideal types served to make some kind of order in the many registered roles of change agents and allowed us to reflect on how these ideal types relate to different approaches to learning and to sustainability. Applying them to empirical cases, our aim is not to illustrate and confirm the ideal types, but to discuss whether they make sense as heuristic tools, as well as where our empirical material adds to or even contests the value of the presented change agency roles and ideal types. From this perspective, we next compare the ideal typology with empirical examples: one stemming from our case study of a grassroots community center in Belgium, and three examples from a Danish national scheme for local green guides.

The grassroots community center in Belgium runs a café and develops activities in the domains of ecology, international solidarity, culture, and youth work (e.g., making documentary films, selling fair trade products in a shop, and organizing political actions, workshops, a pupils' parliament, and concerts). During interviews and observations, the center's coordinator showed strong engagement. Regularly, he expressed concern for and emotional involvement with people affected by sustainability problems. For example, talking about making a documentary about climate change and energy poverty in which they interviewed a boy from a poor family, he explained:

\begin{abstract}
Such things will always be rather, not rather but very emotional. That's the audience you'd like to be involved with. [...] Those are the people you like and all, uh, so... yeah... After shooting those scenes... every time we needed quite a while... an hour or two ... to chill out before we could go on. That's heavy stuff, you know, even today. Also when you see that. Even when I see that film for the 20th time, when it's been a while, it'll still fill me with emotions and indignation. And it makes me think, hey man, it's such an indifferent system, there's so much injustice in this shit society, I don't want to have anything to do with that...
\end{abstract}

This excerpt not only shows strong commitment and personal involvement but also reveals how the coordinatior was incapable of accepting what he called an unjust society. This, as well as the way he was observed to argue in debates and in preparing political actions together with volunteers, revealed his aspiration for fundamental social change. As such, he regularly played the role of a revolutionary, striving to build alliances and counter power. He also explicitly mentioned this during an interview:

We want to build kind of a counterforce... We are largely convinced that it is not... through lobbying, or through... persuasion that you can change things somehow, but, but through, well, power is a dirty word, but anyway, through your own force, as a group or also as a group of victims or a target group.

However, to a certain extent, this individual also took the role of an inspirational leader by uniting and empowering followers to achieve the goal of a more just and ecologically sustainable society together. He expressed reluctance against steering individuals toward predetermined outcomes. What he expressly did not want to be was a solution provider:

From the beginning, we have deliberately chosen not to
offer solutions. [...] We'll do the asking, and it's for
people to reflect and think what they... We're not dishing
out any ready-made solutions or ideologies. [...] Many
people find that hard. And that's what they said... I was
expecting to see solutions, but I'm left with even more
questions than, than in the beginning... But I find that,
personally I find that a good thing. So if you can make
people think and question themselves, then that's fine.

His ambition to make people think and to arouse interest in and attention for sustainability problems reveals how this coordinator often played the role of an awareness raiser. The open-endedness implied in not wanting to provide ready-to-use solutions but instead aiming to make people think for themselves does not go with a relativistic stand regarding the issues at stake. On the contrary, he very often expressed concern about the people suffering from unsustainability and injustice. For him, "giving voice to the voiceless" was an explicit aim that became visible in the films and in the arguments he used in debates and political actions. As such, he performed a very particular networker role: he made a lot of efforts to bring actors together and to invite new actors and stimulate them to voice their perspectives, concerns, and opinions, yet with a strong focus on the people affected by sustainability issues. During all the activities we observed, plenty of time was taken for in-depth discussions; divergent points of view were elaborated, clarified, and sometimes refined or revised. By collaborating with poverty organizations, community arts projects, unions, and other such organizations, the coordinator deliberately tried to involve "victims" of our current unjust and unsustainable society. He sought to build coalitions with them, looking for solutions together and supporting grassroots initiatives. In doing so, he also played the roles of mobilizer, initiator, and facilitator. For instance, when the center organized a concert, one of the musicians turned out to be a fisherman who used sustainable techniques. He talked about the difficulties he faced in trying to compete with the fleet using common intensive fishing methods and about the petition he started to strive for an inshore three-mile $(4.8 \mathrm{~km})$ zone for sustainable fisheries. This encounter was the trigger for making the documentary Fish and Run.

Through producing such documentaries in which the concerns, arguments, interests, and opinions, of diverse actors involved were thoroughly explored and presented, the coordinator can be regarded as a movement intellectual. His sustained efforts to give voice to victims of unsustainability and injustice and to strive for fundamental social change were reflected in the questions he asked while interviewing people and the choices made during editing. As such, he translated existing knowledge into arguments that support the struggle against ecological degradation, poverty, and inequity. Despite his reluctance against offering solutions, this open-endedness was sometimes challenged by his strong commitment to realizing social change. For example, in contrast to previous documentaries, Fish and Run presented possible solutions for more sustainable fisheries instead of solely evoking questions. In doing so, in close collaboration with people suffering from the consequences of mainstream fisheries, the coordinator 
took up the role of visionary by envisioning change and proposing compelling ideas for a sustainable future for the fish as well as the fishers.

Relating these observations and reflections to the matrix on which we built our ideal typology, what is most obvious is the dominance of personal involvement over detachment. However, we observed this change agent combining engagement with taking on roles that are situated on the personally detached side of this axis. Similarly, he oscillated between open-ended and more instrumental roles. This shows, again, that the tensions used to construct the typology cannot be considered as absolute, dichotomist categories. Rather, they help us to analyze and understand concrete change agents' struggles with balancing attention for issues and processes, proper solutions, and a plurality of views.

This change agent's strong personal engagement combined with his striving to realize a more sustainable and just society may lead to the conclusion that he is a Convincer. He shows great commitment and seems to aim instrumentally at a sustainability transition viewed as a value-driven alternative for our current society, which he considers unjust and unsustainable. In contrast, however, he refuses to approach the pursuit of societal change as a linear, managerial process of planned change and strongly emphasizes his concern for stimulating people to think for themselves. Furthermore, he did not appear to ignore others' perspectives or to downplay contestation or dissent. During our observations, we repeatedly observed that divergent points of view were explored and confronted. Considering this, he could also be regarded as a Concerned Explorer, combining strong engagement with an open-ended approach to education, encouraging, or even challenging, people to think critically about possible responses to unsustainability and injustice and viewing sustainability transition as something that demands search, dialogue, and struggle over concrete alternatives.

We supplement this example by discussing how change agents' roles and performance can change over time, drawing on three examples from the study of the Danish national Green Guide scheme (Læssøe 2001). The scheme is interesting for two reasons. First, the scheme did not insist that the green guides apply a conventional instrumental educational approach but allowed them to develop their approach in collaboration with their local partners. Second, the formative evaluation of the scheme enabled a study of the local green guide projects over a period of four years. Eight case studies were conducted, from which we draw three examples on how green guides approached their task and changed their strategies and roles over time.

Although the Green Guide scheme allowed the local partners who were employing the green guides to define their own approach, the majority of them interpreted their task as a matter of informing people about environmentally friendly behavior and trying to activate them in local environmentally friendly projects. This instrumental orientation gave rise to employment of engaged and knowledgably green guides who, as such, typically approached their job in accordance with what we have described as Convincers. However, in several cases, this approach was changed in different directions after 1-2 years.

The green guide in Nørager, a rural municipality with only 5500 inhabitants, did not know the community before he was employed.
Furthermore, he was faced with the task of engaging people in green lifestyles and local green projects at a place without any ongoing efforts to build on but with some resistance in the population, especially in relation to organic food. He started on the offense, was enthusiastic about his task, wrote about environmentally friendly behavior in the local newspaper, and visited local stakeholders in order to establish a network and initiate green projects. His efforts were partly successful. For example, he convinced a local baker to produce organic bread, and he succeeded in establishing a Local Agenda 21 group. The idea was that this group should initiate local green projects, which it did occur, but the projects were initiated and primarily driven by the green guide. For this reason, the motivation and support from engaged citizens began to decrease. The green guide went into a crisis because he realized that his efforts as "first mover" for green projects did not give rise to a process involving local people in creating changes. As a result, he changed his approach from being on the offense and result oriented toward becoming more process oriented, empathic, and responsive to concerns and ideas among the local people. In our typology, it was a move from acting as a Convincer toward an open-ended approach. Because he now was known in the municipality as the green guide, he could not take a position as a neutral mediator. Rather, he moved into a position where he combined the role of facilitator (belonging to the Mediator type) with the identity and role of green awareness raiser (belonging to the Concerned Explorer type). Although this combination in theory seems contradictory, it was possible in this case because the Local Agenda 21 group decided to change from an environmental centered strategy to a strategy in which the survival and development of the nine villages in the municipality became the key issue, in which environmental concerns then became integrated. Thus, the green guide could act as a facilitating resource person for a cross-village committee, and at the same time, the committee could draw on his green expertise.

Other green guides also had problems with their Convincer approach but sometimes changed their strategies in other directions than in the example from Nørager. In the county of West Zealand, for example, a green guide was employed to promote green changes in local societies and sport clubs. The idea was to guide them to start with some easy successful green savings and then let those good examples inspire others. However, that strategy was too optimistic. The dissemination effect did not work. After 1.5 years, the green guide and his partners decided to make a strategic shift by letting the municipalities in the county take over the contact to the societies and clubs and then affiliate the green guide as a consultant. In our typology, this can be described as a move between the two instrumental types, from acting as a Convincer with the role of solution provider to acting as a Technician with the role of expert.

Whereas the first two green guide examples shared a rather conventional starting point, our third example illustrates that others approached their task in quite different ways, creating openings for other kinds of processes and moves in roles. In this case, the green guide was employed by a housing society, Hørgården, with approximately 2000 residents. Among the residents, two-thirds received welfare payments, so the green guide operated in a quite unusual and challenging context. Contrary to the Convincer approach, she began open-endedly by spending some months visiting public areas such as the launderette and the day care institutions and talking with people and getting to know 
them and their concerns. From this starting point, she gradually began to initiate projects together with residents to improve their social and physical environments. In doing so, she acted as a Mediator, enabling and facilitating the residents' own projects. However, she did not hide her green expertise but, based on the position of trust and popularity, she began to inspire the residents to make local green improvements. In this way, the open-ended approach that she had applied from the beginning became combined with a role as Technician/expert.

\section{CONCLUSION: AN IDEAL TYPOLOGY AS A LANDSCAPE}

As our discussion shows, developing an ideal typology inevitably involves a tension between acknowledging complexity and offering conceptual clarification. Any ideal typology faces limits in this respect, and both the development and the use of it always involves risks such as oversimplification, decontextualization, splitting apart theoretically or analytically what cannot be completely separated in concrete practices, and overlooking exceptions or combinations or things in between the demarcated categories. It is therefore important to emphasize that we developed this ideal typology of sustainability change agents as facilitators of nonformal learning as a flexible and makeshift heuristic model hoping that, as a conceptual tool, it can inspire future theoretical and empirical research as well as stimulate reflection among change agency practitioners. Both for research and professional reflection on action, we invite potential users to employ the presented typology not as a rigid framework with monolithic categories but, instead, as a heuristic tool to explore the varied landscape through which concrete change agents navigate and in which they explore, take up, and combine different positions. Thus, the typology can be helpful to clarify the challenges that change agents face while acting in a complex, multidimensional world.

Our discussion of the Belgian case, for instance, reveals how the way that this change agent navigates between and across different roles bearing some resemblance with the ideal types of the Convincer and Concerned Explorer affects his performance as a facilitator of nonformal learning. To a certain extent, he acts in line with both the knowledge creation and response metaphor, opening a space for subjectification, disidentification, and creativity. His concern for vulnerable people affected by unsustainability and injustice, however, seems to be continuously challenging him to make context-specific judgements on how to act. Sometimes, exposing his commitment serves as an invitation for others to become interested, involved, and formulate a critical, personal response. At other occasions, however, the enthusiasm and firmness characterizing his interventions may prevent others (e.g., less self-confident participants) to voice their points of view and as such steers dialogues and joint actions in a certain direction. Furthermore, educational ideals that are at first sight open-ended, such as thinking critically, taking a personal stand, being attentive to power relations, or engaging in pluralistic, conflictual debates, can also become (alternative) preset norms and values into which one strives to socialize people or skills to be acquired through particular educational practices. Indeed, we also observed this coordinator working within an acquisition metaphor (e.g., planning to set up a film school to teach young people particular competencies so that they can "give voice to the voiceless" in critical documentaries) and a socialization metaphor (e.g., expecting certain attitudes and behaviors from people that want to be part of the grassroots center according to their norms and values) for learning. In contrast, the Danish examples point to the importance of not staying in a fixed position by showing how sustainability change agents were pushed to reconsider and change their approaches over time because of the socio-cultural processes they were part of and the experiences they gained. So, rather than pinning empirical examples on a particular position within the matrix, the typology should allow researchers to develop and investigate heat maps of how, in concrete practices, change agents move between and across different positions according to changing and shifting contexts.

In this respect, it is vital to realize that a "best practice" of sustainability change agency, that is, a preferred or ideal (in the sense of perfect, consummate) type of change agent based on an optimal combination of roles does not exist. Rather, sustainability problems seem to require the capability to navigate flexibly and reflectively through the varied landscape based on careful judgement of the specific context in which one is acting. Change agency, then, is very much about grasping multidynamic complexity and finding ways forward, a challenge that is interestingly captured in how political scholars describe the "messiness, accident, fortuitous coupling, and dumb luck" (Kingdon 1984:206) involved in the work done by "policy entrepreneurs" (Mintrom 1997, Zahariadis 2007, Block and Paredis 2013). There are advocates of certain problems and solutions who are willing to invest resources (time, energy, reputation, money) to promote their ideas for policy change and try to influence the decision agenda by coupling several crucial streams that flow through the system: a stream of problems, policies, and politics (Kingdon 1984). When a problem receives attention, a policy solution is available in the "primeval soup" of ideas, and the political climate is receptive, then a moment for pushing change has arrived: a policy window. Policy entrepreneurs try to create and respond to these moments, thereby "hook[ing] solutions to problems, proposals to political momentum, and political events to policy problems" (Kingdon 1984:182). Hence, they cannot be pinned down to one particular type of change agency but navigate through our ideal typology, drawing on very different roles precisely with the aim of coupling processes and creating policy windows.

As our empirical cases illustrate, the drivers for such navigation can be diverse: changing socio-cultural contexts over time, responses from stakeholders, the specificity of issues, and other drivers. When facing a structured problem (Fig. 1) or focusing on structured aspects of a sustainability problem, for instance, more instrumental change agency roles and interventions are well suited to facilitate change. Wicked or unstructured problems, however, often demand more complexityacknowledging types and roles that imply a less linear and mechanistic and more open-ended approach to sustainability and learning. As previous research (e.g., Læssøe 2007, Van Poeck et al. 2017) has shown that the latter receive too little attention in change agency practices, an important challenge is to create and maintain openness to engage with the whole range of change agency types and roles. This is important in view of creating a rich learning environment with space for qualification, socialization, and subjectificatio, $\mathrm{n}$ but also to broaden the scope of policy, politics, and change toward a more sustainable society. 
Finally, we hope that researchers will find inspiration in the theoretical and analytical potential of the presented ideal typology to employ it for further investigation of how context matters in sustainability change agents' roles and practices. We suggest a number of questions that can be addressed in future research. How do change agents move through the landscape of roles and ideal types as they address and respond to different kinds of structured, semistructured, or unstructured sustainability issues? How do different organizational or socio-cultural contexts affect change agents' roles and performances, and how does this relate to the educational dynamics that are enabled or disabled? How do the counterparts of the sustainability change agent respond to their efforts in order to resist change, and how does this influence the role and strategies of sustainability change agents? How do change agents' roles and identities differ or evolve over time and space? What kinds of learning take place in the variety of change agency practices? And finally, can the theoretical connections we made between the identified ideal types of change agents and the elaborated metaphors and functions of education also be observed, elaborated, and contested empirically?

Responses to this article can be read online at: http://www.ecologyandsociety.org/issues/responses. php/9308

\section{Acknowledgments:}

We thank the members of the International Thematic Network "Sustainability education - Teaching and learning in the face of wicked socio-ecological problems" at Ghent University for valuable feedback and constructive comments and suggestions during a discussion of an earlier version of this article.

\section{LITERATURE CITED}

Argyris, C., and D. A. Schön. 1978. Organizational learning: a theory of action perspective. Addison-Wesley, Reading, Massachusetts, USA.

Ashley, M. 2000. Science: an unreliable friend to environmental education? Environmental Education Research 6(3):269-280. http://dx.doi.org/10.1080/713664678

Asplund, J. 1987. Det sociala livets elementära former. Bokförlaget Korpen, Göteborg, Sweden.

Beckhard, R. 1969. Organizational development: strategies and models. Addison-Wesley, Reading, Massachusetts, USA.

Behling, O., and J. M. McFillen. 1996. Syncretical model of charismatic/transformational leadership. Group of Organizational Management 21(2):163-191. http://dx.doi.org/10.1177/1059601196212004

Bennis, W. G. 1964. The change agents. Pages 306-321 in R. T. Golembiewski and A. Blumberg, editors. Sensitivity training and the laboratory approach: readings about concepts and applications. F.E. Peacock, Itasca, Illinois, USA.

Bennis, W. G., and E. H. Schein. 1969. Principles and strategies in the use of laboratory training for improving social systems.
Pages 335-357 in W. G. Bennis, K. D. Benne, and R. Chin, editors. The planning of change. Holt, Rinehart, and Winston, New York, New York, USA.

Biesta, G. 2009. Good education in an age of measurement: on the need to reconnect with the question of purpose in education. Educational Assessment, Evaluation and Accountability 21 (1):33-46. http://dx.doi.org/10.1007/s11092-008-9064-9

Blewitt, J. 2005. Education for sustainable development, governmentality and Learning to Last. Environmental Education Research 11(2):173-185. http://dx.doi.org/10.1080/1350462042000338342

Block, T., and E. Paredis. 2013. Urban development projects catalyst for sustainable urban transformations: the need for entrepreneurial political leadership. Journal of Cleaner Production 50:181-188.

Breiting, S. 2009. Issues for environmental education and ESD research development: looking ahead from WEEC 2007 in Durban. Environmental Education Research 15(2):199-207. http:// dx.doi.org/10.1080/13504620902807584

Buchanan, D. A., and D. Boddy. 1992. The expertise of the change agent: public performance and backstage activity. Prentice Hall, London, UK.

Caldwell, R. 2003. Models of change agency: a fourfold classification. British Journal of Management 14(2):131-142. http://dx.doi.org/10.1111/1467-8551.00270

Dale, A. 1974. Coercive persuasion and the role of the change agent. Interpersonal Development 5(2):102-111.

Engeström, Y. 1999. Innovative learning in work teams: analyzing cycles of knowledge creation in practice. Pages 377-404 in Y. Engeström, R. Miettinen, and R.-L. Punamäki, editors. Perspectives on activity theory. Cambridge University Press, Cambridge, UK. https://doi.org/10.1017/CBO9780511812774.025

Ferreira, J. 2009. Unsettling orthodoxies: education for the environment/for sustainability. Environmental Education Research 15(5):607-620. http://dx.doi.org/10.1080/13504620903326097

Finger, M., and J. M. Asún. 2001. Adult education at the crossroads: learning our way out. Zed Books, London, UK.

Garrison, J., L. Östman, and M. Håkansson. 2015. The creative use of companion values in environmental education and education for sustainable development: exploring the educative moment. Environmental Education Research 21(2):183-204. http://dx.doi.org/10.1080/13504622.2014.936157

Ginsberg, A., and E. Abrahamson. 1991. Champions of change and strategic shifts: the role of internal and external change advocates. Journal of Management Studies 28(2):173-190. http:// dx.doi.org/10.1111/j.1467-6486.1991.tb00276.x

Håkansson, M., L. Östman, and K. Van Poeck. 2017. The political tendency in environmental and sustainability education. European Educational Research Journal. http://dx.doi. org/10.1177/1474904117695278

Hasslöf, H., and C. Malmberg. 2015. Critical thinking as room for subjectification in Education for Sustainable Development. Environmental Education Research 21(2):239-255. http://dx.doi. org/10.1080/13504622.2014.940854 
Hoppe, R. 2010. From "knowledge use" towards "boundary work": sketch of an emerging new agenda for inquiry into sciencepolicy interaction. Pages 169-186 in R. J. in't Veld, editor. Knowledge democracy: consequences for science, politics and media. Springer, Berlin, Germany. http://dx.doi.org/10.1007/978$\underline{-3-642-11381-9 \quad 13}$

Illich, I. 1973. Tools for conviviality. World Perspectives, volume 47. Harper and Row, New York, New York, USA.

Kingdon, J. W. 1984. Agendas, alternatives, and public policies. Little, Brown and Company, Boston, Massachusetts, USA.

Kopnina, H. 2012. Education for sustainable development (ESD): the turn away from 'environment' in environmental education? Environmental Education Research 18(5):699-717. http://dx.doi. org/10.1080/13504622.2012.658028

Læssøe, J. 2001. Evaluering af grøn guide ordningen 1997-2001. Den Grønne Fond/Miljøstyrelsen, Copenhagen, Denmark.

Læssøe, J. 2007. Participation and sustainable development: the post-ecologist transformation of citizen involvement in Denmark. Environmental Politics 16(2):231-250.

Læssøe, J. 2008. Participation and sustainable development: the role and challenges of mediating agents. Pages 144-158 in A. Reid, B. B. Jensen, J. Nikel, and V. Simovska, editors. Participation and learning: perspectives on education and the environment, health and sustainability. Springer, Dordrecht, The Netherlands.

Lewin, K. 1947. Frontiers in group dynamics: concept, method and reality in social science; social equilibria and social change. Human Relations 1(1):5-41. http://dx.doi.org/10.1177/00187267$\underline{4700100103}$

Loorbach, D. 2007. Transition management: new mode of governance for sustainable development. International Books, Utrecht, The Netherlands.

Marimaa, K. 2011. The many faces of fanaticism. KVÜÕA toimetised/ENDC Proceedings 14:29-55.

Marres, N. S. 2005. No issue, no public: democratic deficits after the displacement of politics. Dissertation. University of Amsterdam, Amsterdam, The Netherlands. [online] URL: $\underline{\text { http:// }}$ hdl.handle.net/11245/1.241881

Mayon-White, B. 1993. Problem solving in small groups: team members as change agents. Pages 132-142 in C. Mabey and B. Mayon-White, editors. Managing change. Second edition. Paul Chapman, London, UK.

Mezirow, J. 1991. Transformative dimensions of adult learning. Jossey-Bass, San Francisco, California, USA.

Mintrom, M. 1997. Policy entrepreneurs and the diffusion of innovation. American Journal of Political Science 41(3):738-770. http://dx.doi.org/10.2307/2111674

Mogensen, F., and K. Schnack. 2010. The action competence approach and the 'new' discourses of education for sustainable development, competence and quality criteria. Environmental Education Research 16(1):59-74. http://dx.doi.org/10.1080/1350$\underline{4620903504032}$
Öhman, J., and L. Östman. 2008. Clarifying the ethical tendency in education for sustainable development practice: a Wittgenstein-inspired approach. Canadian Journal of Environmental Education 13(1):57-72.

Osberg, D., and G. Biesta. 2010. The end/s of education: complexity and the conundrum of the inclusive educational curriculum. International Journal of Inclusive Education 14 (6):593-607. http://dx.doi.org/10.1080/13603110802530684

Ottaway, R. N. 1983. The change agent: a taxonomy in relation to the change process. Human Relations 36(4):361-392. http://dx. doi.org/10.1177/001872678303600403

Ottaway, R. N., and C. L. Cooper. 1976. Moving towards a taxonomy of change agents. Management Education and Development 7(3):177-186. https://doi.org/10.1177/135050767600700304

Paavola, S., L. Lipponen, and K. Hakkarainen. 2004. Models of innovative knowledge communities and three metaphors of learning. Review of Educational Research 74(4):557-576. http:// dx.doi.org/10.3102/00346543074004557

Paredis, E. 2013. A winding road: transition management, policy change and the search for sustainable development. Dissertation. Ghent University, Ghent, Belgium. [online] URL: http://hdl. handle.net/1854/LU-4100031

Patton, M. Q. 2002. Qualitative research and evaluation methods. Third edition. Sage, Thousand Oaks, California, USA.

Pryshlakivsky, J., and C. Searcy. 2013. Sustainable development as a wicked problem. Pages 109-128 in S. F. Kovacic and A. SousaPoza, editors. Managing and engineering in complex situations. Springer, Dordrecht, The Netherlands. http://dx.doi. org/10.1007/978-94-007-5515-4 6

Saravanan, V. S. 2015. Agents of institutional change: the contribution of new institutionalism in understanding water governance in India. Environmental Science and Policy 53 (B):225-235. http://dx.doi.org/10.1016/j.envsci.2015.01.012

Schein, E. H. 1988. Process consultation, volume 1: its role in organization development. Addison-Wesley, Reading, Massachusetts, USA.

Schein, E. H. 1996. Kurt Lewin's change theory in the field and in the classroom: notes toward a model of managed learning. Systems Practice 9(1):27-47. http://dx.doi.org/10.1007/BF02173417

Sfard, A. 1998. On two metaphors for learning and the dangers of choosing just one. Educational Researcher 27(2):4-13. http:// dx.doi.org/10.3102/0013189x027002004

Starks, H., and S. Brown Trinidad. 2007 Choose your method: a comparison of phenomenology, discourse analysis, and grounded theory. Qualitative Health Research 17(10):1372-1380. https://doi. org/10.1177/1049732307307031

Sund, L., and J. Öhman. 2014. On the need to repoliticise environmental and sustainability education: rethinking the postpolitical consensus. Environmental Education Research 20 (5):639-659. http://dx.doi.org/10.1080/13504622.2013.833585 
Tichy, N. M. 1974. Agents of planned social change: congruence of values, cognitions and actions. Administrative Science Quarterly 19(2):164-182. http://dx.doi.org/10.2307/2393887

Tichy, N. M. 1975. How different types of change agents diagnose organizations. Human Relations 28(9):771-779. http://dx.doi. org/10.1177/001872677502800901

Van Poeck, K., G. Goeminne, and J. Vandenabeele. 2016. Revisiting the democratic paradox of environmental and sustainability education: sustainability issues as matters of concern. Environmental Education Research 22(6):806-826. http:// dx.doi.org/10.1080/13504622.2014.966659

Van Poeck, K., and J. Vandenabeele. 2014. Education as a response to sustainability issues. European Journal for Research on the Education and Learning of Adults 5(2):221-236. [online] URL: http://www.rela.ep.liu.se/article.asp?.DOI=10.3384/rela.2000-7426. $\underline{\text { rela0111 }}$

Van Poeck, K., J. Vandenabeele, and G. Goeminne. 2017. Making climate change public? A dramaturgically inspired case-study of learning through transition management. International Journal of Global Warming, in press.

Vandenabeele, J., and D. Wildemeersch. 2012. How farmers learn about environmental issues: reflections on a sociobiographical approach. Adult Education Quarterly 62(1):56-72. http://dx.doi. org/10.1177/0741713610392770

Walker, P. 2006. Supporting the change agents: keeping ourselves effective on the journey of change. Greener Management International 54:9-22. https://doi.org/10.9774/GLEAF.3062.2006. $\underline{\text { su.00004 }}$

Walker, P. 2007. What's it like from the inside? Challenges of being an organisational change agent for sustainability. Greener Management International 57:9-25. https://doi.org/10.9774/ GLEAF.3062.2007.sp.00003

Webber, P. 1999. Learning for a change. Fast Company 24:178-183. [online] URL: https://www.fastcompany.com/36819/learningchange

Weber, M. 2011. Methodology of social sciences. Translated and edited by E. A. Shils and H. A. Finch. Transaction, New Brunswick, New Jersey, USA.

Wickenberg, P. 2004. Norm supporting structures in environmental education and education for sustainable development. Pages 103-130 in P. Wickenberg, H. Axelsson, L. Fritzén, G. Helldén, and J. Öhman, editors. Learning to change our world? Swedish research on education and sustainable development. Studentlitteratur, Lund, Sweden.

Wildemeersch, D., T. Jansen, J. Vandenabeele, and M. Jans. 1998. Social learning: a new perspective on learning in participatory systems. Studies in Continuing Education 20(2):251-265. http://dx. doi.org/10.1080/0158037980200210

Wittgenstein, L. 2010. Philosophical investigations. Translated by G. E. M. Anscombe, P. M. S. Hacker, and J. Schulte. Revised fourth edition. Wiley-Blackwell, Oxford, UK.
Zahariadis, N. 2007. The multiple streams framework: structure, limitations, prospects. Pages 65-92 in P. A. Sabatier, editor. Theories of the policy process. Westview Press, Boulder, Colorado, USA.

Zaltman, G., and R. Duncan. 1975. Strategies for planned change. Wiley, New York, New York, USA. 